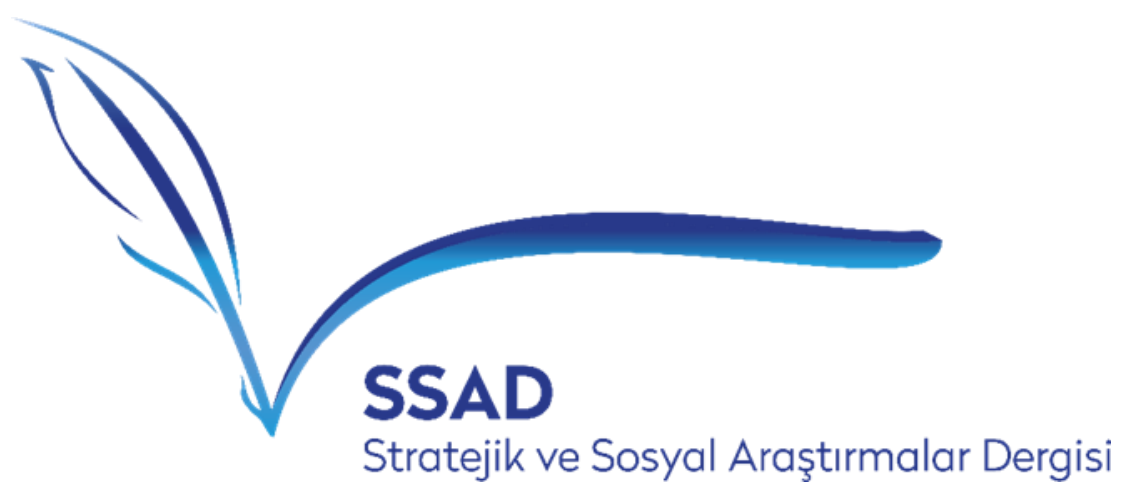

ISSN: 2587-2621

Volume 4 Issue 3, November 2020

ORCID ID: 0000-0002-6389-7375

Makale Gönderim Tarihi: 27.10.2020

Makale Kabul Tarihi: 12.11.2020

DOI: 10.30692/sisad.816976

\title{
THE POLITICAL STATUS OF KOSOVO (1967-1974): BETWEEN SERBIAN HEGEMONY AND SELF-RULE
}

\section{Kosova'nın Siyasi Statüsü (1967-1974): Sırp Hegemonyast ve Özyönetim Arasında}

\author{
Memli KRASNIQI \\ Assoc. Prof. Dr. \\ The Institute of Albanology \\ Republic of Kosova \\ memlikr@hotmail.com
}

\begin{abstract}
Özet: 1966'dan 1980'e kadar olan dönem, Kosova'da ikinci Arnavut siyasi ve kültürel Rönesans'1 olarak değerlendirilir. Bu tarihler arasında Kosova olabilecek en yüksek özerkliğe ulaştığı dönemdir. Bir yandan Sırbistan'ın Kosova'ya hiçbir şekilde özerklik vermeme çabası, diğer yandan ise Arnavutların Kosova'da Yugoslavya'nın diğer federe bölgeleri kadar özerklik ve Sırbistan etkisinden kurtulma çabası içinde olma çabası görülmektedir. Yugoslavya Sosyalist Federal Cumhuriyeti'ndeki durum, bir taraftan Sırplar ve Karadağlılar tarafından istenilen merkezi bir federasyon kavramı dururken, diğer yandan ise kuzey cumhuriyetleri olan Slovenya ve Hırvatistan tarafindan istenen merkezi olmayan bir liberal yönetim sistemi talebi bulunmuş ve uzun bir iç rekabet devam ettiği görülmüştür. 1966'dan, Josip Broz Tito'nun ölümüne kadar olan dönemde Yugoslavya'daki federe cumhuriyetleri kadar, Kosova ve Voyvodina vilayetlerinde de daha fazla siyasi ve ekonomik yetkiler verilerek daha fazla demokratikleşme kavramı hâkim olduğu gözlemlenmiştir.
\end{abstract}

Anahtar Kelimeler: Kosova, Yugoslavya, Arnavutlar, Sırbistan, Özyönetim. 


\begin{abstract}
The time from 1966 until 1980 in Kosovo is known as second Albanian cultural and political reborn. It was time when Kosovo had achieves the highest possible autonomy, which was compromise between Serbian tendencies to not allow any form of self-government to Kosovo and the political goal of Albanians for at least the status of Republic for the Kosovo, independent from the Republic of Serbia and equal part of the Yugoslavian Federation. The state of SFR of Yugoslavia it had a long history of inner rivalry between the concept of centralized federation, which was mostly supported by Serbs and Montenegro's, and more liberal and decentralized state, advocated by northern republics (Slovenia and Croatia). From 1966 and until the death of Josip Broz Tito in Yugoslavia, prevail the political concept of further democratization, with more political and economic power distributed to the republics and provinces of Kosovo and Vojvodina.
\end{abstract}

Keywords: Kosovo, Yugoslavia, Albanians, Serbia, Self-rule.

\title{
INTRODUCTION
}

In the collective memory of Albanians in Yugoslavia, the historic period from 1944-66 was remembered as the epoch of Aleksandar Rankovic, the former Minister of Interior and Vice President of Yugoslavia, a period during which Albanians were killed, imprisoned and mass displaced in Turkey. The Serbian-Montenegrin political elite, moreover, contrary to the principles of the communist ideology on national and social equality, although formally allowing the limited use of the Albanian language, which they contemptuously called "Shiptarski", persecuted and imprisoned almost every Albanian intellectual. However, the fall of Aleksandar Rankovic and the Serb-Montenegrins-controlled UDB (Internal State Security Service) came primarily as a product of the contradictions between the two political concepts; that Serbian hegemonic and centralist and the Croatian-Slovenian one, for more decentralization in both the economic and political spheres with more autonomy and powers for the federal units. The fact that the President of the country, Josip Broz Tito, was spied, accelerated the organization of the "Brioni Plenum" of the Communists League of Yugoslavia (1966), in which Aleksandar Rankovic resigned from all powers. While the repressive policy of the UDB, particularly against the Albanians, served Tito to convince the Yugoslav public opinion, especially the Serbian one, about the extent of misuse of this service.

Thus, the newspaper "Politika" of September 21, 1966 reported "That in Prishtine it was suspected in everything written in the Albanian language, even in those who read the book "Albania today"of the secretary of the Central Committee of Communist League of Yugoslavia, Veljko Vlahovic, which was published by "Rilindja" in Albanian language (Srbija i Albanci, 1989:84) .

Also, the Belgrade newspaper "Politika" of September 8, 1966, would write that in the meeting of the commission for the reorganization of the Secret Service of Serbia "it was concluded that there were serious abuses in the work of the service, especially in Kosovo-Metohija, mainly against nationalities contrary to their constitutionally guaranteed rights" (Srbija i Albanci, 1989:77). So even in this case there were attempts by the Serbian side to mitigate the accusations of crimes, bypassing the direct mention of Albanians as those who had suffered from this hegemonic policy of the Serb-Montenegrins of Yugoslavia.

The newspaper "Politika" of September 19, 1966, will bring excerpts from the speech of Veli Deva, secretary of the Communist League of Serbia for Kosovo and Metohija (as it was still officially called Kosovo), where he stated that the serious abuses of the secret service against the Albanian citizens, were carried out from 1956 to 1963 (Krasniqi et al., 2016:24), which cover the period of rule of the Khrushchev (USSR) and the weakened international position of Albania. The best example of this was the establishment of the Institute of Albanology in 1953 and its closure in 1955, immediately after the meeting of Khrushchev and Tito in Belgrade (Qosja. 2014:83).

While, one of the first steps of Tito, towards his new policy of decentralization and internal democratization, was undoubtedly the formalization in 1967 of the Muslim nation in Bosnia, as 
an effort of his, among others, to counterbalance the Serb and Croat rivalry in Bosnia, but also to weaken the power of Serbia and of the Serbs in the Yugoslav federation (Kamberović, 2011:274).

The next step of the President of the SFR of Yugoslavia, Josip Broz Tito, was the issue of Albanians and their status in the new configuration of the Yugoslav federation. Thus, in 1967, J.B. Tito had visited Kosovo and where he, for the first time, has spoken openly about the rights of Albanians, thus emboldening the political elite of Kosovo, to engage more boldly in party and state forums requesting the implementation of the proclaimed principles of social, economic, political and status equality of Albanians as a whole, as well as the advancement of the legalpolitical position of Kosovo.

The first sign of the advancement of the position of the Albanians in Yugoslavia, was the decision on 27-28 February 1967 of the Assembly of the Autonomous Province of Kosovo and Metohija, for the reopening of the Institute for Albanology (Qosja, 2014:70). While in Croatia, in 1967, the cultural and scientific institutions of Croatia, among them Miroslav Krleza (the well-known Croatian academic), will signs a statement on the name and position of the Croatian literary language in Yugoslavia as well as against the project for unified Serb-Croat language (Qosja, 2014:78). This was undoubtedly an impetus for the Albanians in Yugoslavia, on April 22-23, 1968, in Prishtina, with the support of the President of the Assembly of the Autonomous Province of Kosovo, Fadil Hoxha, to organize a language consultation and to decide that the Albanians in Kosovo and in Yugoslavia to use the literary language used in Albania (Qosja, 2014:96-97).

Whereas, Fadil Hoxha, member of the Presidency of the Communists League of Yugoslavia and Chairman of the Assembly of the Autonomous Province of Kosovo and Metohija, in his speech of February 12, 1968, would emphasize that the bad relations between Yugoslavia and Albania contribute only to the hegemonic powers, which had no good intentions towards either Belgrade or Tirana. Indeed, Yugoslavia sought the support of Albania and China against pro-Soviet Bulgaria's claims to Macedonia (Hoxha, Surroi, 2010:323). And during 1967-68, Bulgaria, with the support of the USSR, launched a campaign against the Macedonian nation and language as well as claims according to San Stefano Treaty (1878). This was a kind of pressure of the Eastern Block on Yugoslavia, considering that this country was entering in the process of disintegration, with internal ethnic conflicts and clashes between federal units. Consequently, the revival of the debates from the history and the contestation of the territorial integrity of Yugoslavia was a reminder of the claims of Bulgaria toward Vardar Macedonia, to Greece, but also to the part of political Albania. At the same time, this was a form of pressure by URSS against the policy of further democratization of Yugoslavia. This was not just a Bulgarian propaganda, because as the organizer of the celebration of the 90th anniversary of the San Stefano Treaty (1878) was the Bulgarian-USSR Friendship Association. Therefore, it is very logical that Yugoslavia, through the speeches of Fadil Hoxha, called for the improvement of relations between Albania and Yugoslavia, against the territorial pretences of Bulgaria, as well as against the hegemonic policy of foreign powers, namely the USSR (Rusinow, 1968/ 2012:1-2).

The President of Yugoslavia, Josip Broz Tito, on July 9, 1968, through Belgrade Television, would address to citizens of Yugoslavia and where he publicly acknowledged the omissions of the Communists League of Yugoslavia in relation to students, such as their social problems, employment, abuse of communists, allowing the opening of private factories, etc. Tito also refuted claims that these demonstrations were allegedly driven by the same events in Europe, stressing that the causes that sparked student dissatisfaction lie. Immediately after his speech, the students stopped the protests. This means that the leftist movement in Europe during 60-s was still very strong and not at all liberal (Muzej Istorije Jugoslavije, 1968).

On the strategic level, the invasion of Czechoslovakia by the USSR and the Warsaw Pact in August 1968 brought Albania and Yugoslavia closer to their policy of preserving independence. In October 1968, the Committee on Constitutional Amendments of the Federal Assembly of Yugoslavia approved the amendment, which in Article 2 of the constitution stated that the 
Yugoslav federation, in addition to the 6 republics, included the Autonomous Province of Vojvodina and the Autonomous Province of Kosovo and Metohija. Also, the Federal Assembly would consist of the Chamber of Nations and Nationalities, where the republics and provinces would be represented (Rilindja, 1 Nantor 1968:1).

In the 1968 meeting, organized between Tito and the delegation of the Provincial Committee of the Communists League of Kosovo and Metohija, with participants: Veli Deva, Fadil Hoxha, Ilija Vajic, Iljaz Kurteshi, Blazo Radonjic and Ismajl Bajra, various topics were discussed, such as the economic development of Kosovo, national equality, the amendments related to some provisions of the constitution of Yugoslavia, etc. At this meeting with Tito, the Kosovo delegation emphasized the overcoming of two opposing tendencies, one calling for nothing to change in Kosovo's status and the other regarding demands for Kosovo as a Republic. Tito stressed that the Autonomous Province of Kosovo should enjoy all the rights that belong to it and that he would personally be committed to sifting the problems of Kosovo and Metohija into the Federation and in the Republic of Serbia. Above all, Tito emphasized the lack of economic development of Kosovo, which is the source of political, social problems and strained interethnic relations. The President of the SFR of Yugoslavia also spoke about the issue of high unemployment in Kosovo, so he promised to invest in public works such as: roads, construction of infrastructure facilities, as well as investments in the construction of production capacity but also in agriculture, which would alleviate the problem of unemployment and poverty. Tito also spoke about the national structure of employees in Kosovo, which was not fair. However, he stressed, that the problem is not solved by firing Serbs and Montenegrins, but with a fair policy, which in the inclusion of new workers must be in accordance with the national structure of the population in Kosovo.

Regarding the amendments to some provisions of the Constitution of the SFRY, Tito stressed that the Autonomous Province should enjoy all the rights that belong to it, so it should have a full content, because the status of republic is not the only factor that solves all problems. Therefore, Tito would emphasize, if the autonomy is complete, then even with this form it could solve all the economic, social, political and cultural problems of a respective territory. And at the end Tito asked: Why not to call the Autonomous Province as socialist? The name Socialist Autonomous Province seemed to be promoting the status of Kosovo at a higher level, although not equal to the status of republic. He stressed that one thing should be known: "Anything that means equality for a nation or a nationality must be sought and ensured." Also for the first time, after almost a quarter of a century, Tito will declare that the people of Kosovo and Metohija must feel that someone cares about them. He expressed his gratitude especially for the activists of the Communists League from the ranks of Albanian nationality (Rilindja, 4 Nantor 1968:5).

So, the support that Tito offered to the Albanians, was also the merit of the Albanian State, which at least from 1948 onwards, had supported the rights of the Albanians in Yugoslavia, using the diplomatic channels for complaints to the countries of the Eastern Bloc (with a limited success until 1955), then supporting and inciting illegal Albanian resistance in Yugoslavia. However, with the withdrawal of Albania from the Warsaw Pact (1961 and 1968), its interests in foreign policy were intertwined with those of Tito's Yugoslavia. Also the illegally organized resistances of the Albanians in Yugoslavia made Tito to understand that, in order to continue his deep economic, social, administrative and political reforms, he must also face the problem of the Albanians. And Tito, as a pragmatic politician capable of neutralizing enemies, will offer to the political elite of Kosovo Albanians, support to the extent of Kosovo's status "more than autonomy less than a republic."Fadil Hoxha, would also later point out that they, the Albanian politicians, wanted to know how far they could go in their demands and how ready Tito was to tell the Serbs that we could not quarrel with Kosovo. Therefore, Fadil Hoxha will stress, that the official request for the Kosovo as Republic would have been used by the Serbs, who accused the Albanians of separatist tendencies (Hoxha, Surroi, 2010:362).

The favorable climate for Albanians was used to express their demands in the demonstrations of November 1968. On December 26, 1968, the Federal Assembly of Yugoslavia adopted 
constitutional amendments, which gave the autonomous provinces constitutional law, paving the way for an independent legislative and with judicial and executive power. Kosovo also officially began to be called the Autonomous Socialist Province of Kosovo.

The 9th Congress of the Communist League of Yugoslavia held on March 11, 1969, finally said goodbye to the old political guard. Almost $70 \%$ of the members of the Central Committee of Communists League in the republics were young cadres, while the average age of the members of the Central Committee of Communists League of Yugoslavia was 45 years old. Thus, the CIA in its report stated that after this decentralization process, even in the event of Tito's death, was unlikely to lead Yugoslavia to anarchy. Also, his authority could not be replaced by anyone in Yugoslavia, so the system of collective leadership was the best way to inherit Tito. The selfgoverning system in the economy had given economic entities greater independence in decisionmaking, making them more profit-oriented as market economy. Substantial changes were made in the organization of state security, decentralizing it to federal units, as well as with passing the law that allowed federal units to organize Territorial Defense, as a kind of guerilla army and that actually enabled federal units to lay the foundations for the republic military forces (Weekly Summary Special Report, 7 March 1969/2005:2-5).

During the Brioni meeting where constitutional changes were discussed, Serbia encouraged Serbs in the Prizren and Serb students at the University of Pristine to protest, which was as a form of pressure on Kosovo and Tito (Hoxha, Surroi, 2010:350). In 1971, after the defeat of the Croatian movement, the "liberals" of Serbia (Marko Nikezic and Latinka Perovic) tried ostensibly on a liberal anti Tito platform to gain the support of Veli Deva. Of course, the Kosovo political elite, who did not want to become an outstretched hand of the Serbian hegemonic tendencies, hidden behind liberal ideas, also informed Tito about this, which sometimes later would dismiss this group of Serbian nationalists (Hoxha, Surroi, 2010:369-370).

In 1972, Yugoslavia received a loan of \$ 1.3 billion from the USSR, which would be used in the energy, metallurgy and chemical industries. The finalization of these agreements would be done by companies from Yugoslavia, which would negotiate directly with the USSR institutions. These political loans were the tool that enabled the USSR to deepen its economic and political influence in some federal units of Yugoslavia. While Mahmut Bakalli, President of the Communists League of Kosovo, on September 7, 1972, in Kamenica, following Tito's criticism against nationalism, spoke of vigilance against Albanian nationalism, leaving Tito to understand that the message against any explosion of Albanians was understood by the Kosovo leadership (Eastern European Intelligencer, 8 September 1972/ 2007:1-2).

Regarding these rights of Kosovo and Albanians, and difficulties to achieve them, also were testified by Prof. Dr. Fazli Syla, former director of the Institute of Albanology, who was also the Provincial Secretary for Education, Culture and Science of the Autonomous Socialist Province of Kosovo (1974-78). He stated that the Kosovo leadership had asked him that Kosovo also should have all the cultural, scientific and educational institutions as had Slovenia, Croatia or Serbia. The greatest resistance of Serbia and Yugoslavia was against the establishment of the Academy of Sciences and Arts, and the International Seminar on Albanian Language, Literature and Culture (1974). The President of the Serbian Academy of Sciences and Arts, Pavle Savic, until the last moment refused to participate in the commission for the admission of Kosovar academics and the establishment of the Kosovo Academy of Sciences and Arts (1975). Eventually the Serbian Academy of Sciences and Arts sent Dusan Kanazir, who also became chairman of the parent commission for the establishment of the Kosovo Academy of Sciences and Arts (Syla, 2015:89).

During Tito's 1975 visit to Kosovo, he would talk about Kosovo's economic development and political stability. He criticized the northern republics for resisting their obligations to the underdeveloped fund, but promised to increase aid to Kosovo. He also stressed the risk from foreign powers who are acting to destabilize Kosovo. Tito also stressed that he believed that the Albanian leadership wanted to improve relations with Yugoslavia, in order to stabilize the 
situation in this part of the Balkans (Soviet Union Eastern Europe, 7 April 1975/ 2005:2). Finally, I want to emphasize once again that Fadil Hoxha in his memoirs stressed that the constitution of 1974 was not imposed by the Albanians, because the Albanians were not able to impose this solution on either Yugoslavia or Tito. According to him, it was Tito himself which had helped Kosovo a lot (Hoxha, Surroi, 2010:343, 363). 


\section{RREFERENCES}

Eastern European Intellingencer (1972, September 8 / 2007). Yugoslav-Soviet Economic Ties Draw Closer. Retrieved from https://www.cia.gov/library/readingroom/docs/CIARDP79B00864A001200020069-2.pdf.

Hoxha, F., Surroi, V. (2010). Fadil Hoxha në vetën e parë - Me shënime dhe parathënie të Veton Surroit. Prishtinë: Koha.

Krasniqi, M., Matoshi, H., Ahmeti, N., Boçi, S., Dushku, L, Ahmeti, Sh (2016). Kujtesa Kolektive: Dëshmi dhe Ngjarje 1944-66. Prishtinë: Instituti Albanologjik.

Kamberović, H. (2011). Josip Broz Tito i nacionalni identitet Muslimana u Bosni i Hercegovini - dva viđenja. Tito - Viđenja i Tumačenja, p. 274, pp. 274-282.

Dennison, I. R. (1968). The Macedonian Question never dies. Southeast Europe Series (Vol. XV, No.3, p.1-2). Retrieved from https://www.cia.gov/library/readingroom/docs/CIARDP08C01297R000400240004-0.pdf.

Rilindja, 1 nantor 1968, p. 1.

Rilindja, 4 nantor 1968, p. 5.

Syla, F. (2015). Në rrjedhat e Kohës: Dëshmi dhe Përjetime. Prishtinë: Libri shkollor.

Tito speaks in Kosovo (1975, April 7 /2005). Soviet Union, Eastern Europe. Retrieved from https://www.cia.gov/library/readingroom/docs/CIA-RDP79T00865A000700180001-6.pdf

Srbija i Albanci (1989). URN:NBN:SI:doc-KV1QV18Q. Retrieved from http://www.dlib.si

Muzej Istorije Jugoslavije (1968, jun 9). Tito govori studentima. Beograd: Tv Beograd. Retrieved from https://www.youtube.com/watch?v=Nne2feNUEu8.

Qosja, R. (2014). Dëshmitar në kohë historike (1966-1974), Ditari I . Tiranë: Toena.

Weekly Summary Special Report (1969, March 7). Yugoslavia: The Passing of the Old Guard. Retrieved from https://www.cia.gov/library/readingroom/docs/CIA-RDP7900927A006900060002-1.pdf 